\title{
A comparative proteomic study of sera in paediatric systemic lupus erythematosus patients and in healthy controls using MALDI-TOF-TOF and LC MS-A pilot study
}

Anita Rana ${ }^{1}$, Ranjana W Minz ${ }^{1 *}$, Ritu Aggarwal' ${ }^{1}$ Sadhna Sharma², Neelam Pasricha', Shashi Anand ${ }^{1}$ and Surjit Singh ${ }^{3}$

\begin{abstract}
Background: Paediatric systemic lupus erythematosus (pSLE) exhibits an aggressive clinical phenotype with severe complications and overall poor prognosis. The aim of this study was to analyse differential expression of low molecular weight (LMW) serum protein molecules of pSLE patients with active disease in comparison to sera of healthy age matched controls. Further, some of the differential expressed spots were characterised and identified by Matrix Assisted Laser Desorption Ionization Time of Flight Mass Spectrometry (MALDI-TOF-MS) and liquid chromatography (LC-MS).
\end{abstract}

Methods: 2D-PAGE was performed using pooled sera of active PSLE and age matched healthy controls. Gels were silver-stained and differentially expressed protein spots were detected by automated image master platinum 2D software. $79 \pm 17$ protein spots were detected for control gels and $78 \pm 17$ protein spots for patient gels. Of these eleven protein spots were selected randomly and characterized by MALDI-TOF MS (five protein spots) and LC MS (six protein spots) techniques.

Results: Out of the 11 protein spots, 5 protein spots were significantly upregulated viz., leiomodin 2 (LMOD2); epidermal cytokeratin 2; immunoglobulin kappa light chain variable region; keratin 1 and transthyretin (TTR). Three protein spots were significantly down regulated e.g., apolipoprotein A1 (APOA1); chain B human complement component C3c; campath antibody antigen complex. Two protein spots (complement component C3; retinol binding protein (RBP) were found to be expressed only in disease and one protein spot cyclohydrolase 2 was only expressed in controls.

Conclusions: We conclude that 2-D maps of patients with active pSLE and controls differ significantly. In this pilot study, using proteomic approach we have identified differential expressed proteins (of LMW) e.g., RBP, LMOD 2, TTR, Component C3C Chain B and APO A1. However, in future, further studies need to confirm the physiological and pathological role of these proteins in similar cohorts of pSLE.

Keywords: Paediatric systemic lupus erythematosus, Two dimensional poly acryl amide gel electrophoresis, Matrix assisted laser desorption ionization time of flight, Liquid chromatography mass spectrometry, Retinol binding protein, Leiomodin 2, Transthyretin, Apolipoprotein A1

\footnotetext{
* Correspondence: rwminz.minz88@gmail.com

'Department of Immunopathology, Post Graduate Institute of Medical

Education and Research (PGIMER), Chandigarh 160012, India

Full list of author information is available at the end of the article
} 


\section{Background}

Systemic lupus erythematosus (SLE) is chronic autoimmune disease with unknown aetiology and complex pathogenesis. pSLE is more severe and exhibits a more aggressive clinical course than adults. Genuine difficulties are faced in diagnosing, classifying, and treating pSLE.

A proteomic approach is necessary to find proteins expressed in the disease states, which may serve as diagnostic or prognostic marker, or serve as targets for therapeutics. Such an approach has yielded newer diagnostic proteins in the other autoimmune diseases viz., myelin protein Po in autoimmune inner ear disease [1], heterogeneous nuclear ribonucleoprotein $\mathrm{A} 2 / \mathrm{B} 1$ in autoimmune hepatitis, ?-enolase in Behcet's disease [2], ?-enolase and its citrullinated molecule in rheumatoid arthritis [3-7]. Traditional methods, such as ELISA or western blotting, can only study several known proteins simultaneously. On the contrary, 2-dimensional poly acryl amide gel electrophoresis (2D-PAGE) combined with protein identification by mass spectrometry (MS) which can help to identify a very large number of unknown proteins $[8,9]$. Proteomic approaches in autoimmune diseases are also required in addition to gene expression studies as the latter has many limitations. First, diseases manifest not at the level of RNA transcription, but rather at the level of the protein. Second, there is a frequently non predictive correlation between RNA expression and protein expression and function [10,11]. Messenger RNA undergoes a variety of processing events that can profoundly affect cell phenotype yet are not revealed in current transcriptional profiles [12-14]. Third, protein function can be regulated by posttranslational modifications by enzymes such as kinases or proteases.

In the present study, we attempted a proteomic approach and performed comparative protein analysis of sera of pSLE and healthy control subjects by 2D-PAGE followed by Matrix Assisted Laser Desorption Ionization and time of flight (MALDI-TOF) and Liquid chromatographymass spectrometry (LC-MS) for the identification and characterization of limited number of some significantly expressed proteins spots. The function and classification of these proteins were then determined by searching the public database.

\section{Methods}

Forty consecutive pSLE patients (5-16 years of age) were recruited from the Division of Allergy Immunology, Advanced Paediatrics Centre, Post Graduate Institute of Medical Education and Research (PGIMER), Chandigarh, India. The diagnosis of pSLE patients was based on the American College of Rheumatology (ACR) criteria for classification [15]. Twenty healthy and age-matched volunteers served as controls. Study was carried out between March 2007 and April 2011. The mean age of the
pSLE patients was 15.2 years (range $5-16$ ). The median SLE Disease Activity Index (SLEDAI) scores were 15 (range of period 4-26) [16]. All patients were positive at a significant titer for antinuclear antibodies included in the study. Patients with overlap syndrome were excluded from the study. All patients were on treatment using standard protocols incorporating, glucocorticoids and immunosuppressive agents (e.g. cyclophosphamide and azathioprine). Patient information in regard to demographic data, cumulative clinical features, serological profile, and medications were retrieved from medical records (shown in Table 1). The study protocol was approved by the Institute Ethics Committee. All parents/ guardians of pSLE patients gave a written informed consent.

Table 1 Demographics and clinical parameters of paediatric lupus patients and control groups

\begin{tabular}{|c|c|c|c|}
\hline Variables & $\begin{array}{l}\text { pSLE } \\
(N=40)^{1}\end{array}$ & $\begin{array}{l}\text { Controls } \\
(\mathrm{N}=20)^{1}\end{array}$ & $p$ value ${ }^{2}$ \\
\hline \multicolumn{4}{|l|}{ Age (years) } \\
\hline Median & 12 & 13 & 0.213 \\
\hline Range & $5-16$ & $10-15$ & \\
\hline Sex (Female/male) & $34 / 6$ & $15 / 5$ & 0.326 \\
\hline \multicolumn{4}{|l|}{ Disease duration (months) } \\
\hline Median & 8 & NA & \\
\hline Range & $1-96$ & NA & \\
\hline \multicolumn{4}{|l|}{ SLEDAI score } \\
\hline Median & 15 & NA & \\
\hline Range & $4-26$ & & \\
\hline \multicolumn{4}{|l|}{ Clinical manifestations $^{1}$} \\
\hline Cutaneous & $25(62.5)$ & NA & \\
\hline Skin Biopsy & $13(32.5)$ & NA & \\
\hline Renal & $24(60)$ & NA & \\
\hline Renal Biopsy & $10(25)$ & NA & \\
\hline Haematological & $18(45)$ & NA & \\
\hline Oral ulcers & $12(30)$ & NA & \\
\hline Musculoskeletal & $12(30)$ & NA & \\
\hline Neurological & $10(25)$ & NA & \\
\hline \multicolumn{4}{|l|}{ Medications used ${ }^{1}$} \\
\hline I. Prednisolone & $11(27.5)$ & & \\
\hline $\begin{array}{l}\text { II. Prednisolone and } \\
\text { anti-malarials (chloroquine } \\
\text { and hydroxychloroquine) }\end{array}$ & $19(47.5)$ & & \\
\hline III. Immunosuppressive therapy ${ }^{3}$ & $10(25)$ & & \\
\hline
\end{tabular}

Abbreviations: SLEDAI SLE disease activity index; Lupus nephritis class based on international society of nephrology/renal pathology society classification criteria (ISN/RPS), NA not applicable, ${ }^{1}$ Values are represented as either median $\&$ range or Number (percentage): $\mathrm{N}(\%) ;{ }^{2} \mathrm{p} \leq 0.05$ as significant; ${ }^{3}$ (methotrexate, azathioprine, mycophenolate mofetil, cyclosporine and cyclophosphamide). 


\section{Serum separation and protein extraction}

Sera were separated from whole blood of pSLE and healthy volunteer children. Blood samples were collected (in autoclaved glass tubes) and left for $1 \mathrm{~h}$ at $37^{\circ} \mathrm{C}$ to allow it to clot. Further, samples were left at $4^{\circ} \mathrm{C}$ overnight to allow the clot to contract. Using a glass pasteur pipette, the clot was loosened carefully from the side of the tube. A care has been taken to not to lyse the red cells as they cannot then be separated from the serum. Serum was centrifuged at $4000 \mathrm{rpm}$ for $20 \mathrm{~min}$ at $4^{\circ} \mathrm{C}$. Serum was removed from the clot by gently pipetting off into a clean tube. It was stored at $-20^{\circ} \mathrm{C}$.

\section{Comparative protein analysis of sera of pSLE and healthy control subjects by 2-Dimensional Poly acryl amide gel electrophoresis (2D-PAGE)}

Protein concentration from sera was estimated by BIORAD protein assay (modified Bradford assay). Mean concentration of protein in sera from control sample was estimated as $66.9 \mathrm{mg} / \mathrm{ml}$ and from SLE disease sample as $65 \mathrm{mg} / \mathrm{ml}$. Proteins $(100 \mu \mathrm{g})$ were cleaned up using 2-D Clean-Up Kit (GE Healthcare) also as described by the manufacturer. The dried protein pellet was then redissolved in $250 \mu \mathrm{l}$ swelling solution containing $7 \mathrm{M}$ urea, $2 \mathrm{M}$ thiourea, 2\% CHAPS, $20 \mathrm{mM}$ DTT and 0.5\% IGP buffer $\mathrm{pH}$ 3-10. 2-D electrophoresis Immobilized $\mathrm{pH}$ gradients (IPG) isoelectric focusing (IEF) of the protein $(100 \mu \mathrm{g})$ was performed according to the guideline of IPG phor IEF system (GE Healthcare, Piscataway, NJ, USA). Thirteen centimetre immobilized $\mathrm{pH}$ 4-7 gradient IPG strips (GE Healthcare, Piscataway, NJ, USA) were chosen, and IEF were run at $20^{\circ} \mathrm{C}$ using the following conditions: $12 \mathrm{~h}$ rehydration, $1 \mathrm{~h}$ at $500 \mathrm{~V}, 1 \mathrm{~h}$ at $1000 \mathrm{~V}$ and at $8000 \mathrm{~V}$ to a total voltage $\times$ time of $60 \mathrm{KVh}$. Strips were then equilibrated by incubating in $6 \mathrm{M}$ urea, 30\% glycerol, $2 \%$ sodium dodecyl sulfate (SDS), $50 \mathrm{mM}$ Tris/Cl pH 8.8 (SDS equilibration buffer solution) containing 1\% DTT, $10 \mathrm{ml}$ per strip for $15 \mathrm{~min}$ at room temperature, followed by an incubation for $15 \mathrm{~min}$ at room temperature in $10 \mathrm{ml}$ per strip SDS equilibration buffer solution containing $2.5 \%$ iodoacetamide and a trace of bromophenol blue. Strips were then placed on top of $12.5 \%$ SDS polyacrylamide gel electrophoresis gels and electrophoresed at 30 milli ampere per gel until the bromophenol blue dye front had reached the bottom of the gel. Each sample was run on duplicate gels.

\section{Silver staining and image analysis}

Gels were silver stained using the improved protocol compatible with mass spectrum analysis [17]. After gel scanning, images were analyzed using Image Master 2D Platinum 5.0 software (GE Healthcare, Piscataway, NJ, USA). For each gel, the preliminary analysis included protein spot detection, editing, filtration and quantification.
Spots were quantitated as a fraction of the total volume of protein spots on the gel. One typical control gel with the most protein spots was then set as reference gel, to which all the other gels were matched. Match rates of each group of gels were calculated automatically by the software. Class report analysis was run on the software and each spot group with a between-class ratio of more than two or less than 0.5 was statistically analyzed using the MannWhitney rank sum test, two-tailed.

\section{MALDI-TOF-TOF-MS and database searching}

The differentially expressed protein spots were excised and collected followed by washing in ex-ion water and destaining through acid ammonium carbonate of $50 \mathrm{mmol} / \mathrm{L}$ plus $50 \%$ acetonitrile. Samples were then treated with trypsin overnight at $37^{\circ} \mathrm{C}$. The peptide segments were drawn through $0.1 \%$ trifluoroacetic acid (TFA) plus $50 \%$ acetonitrile and dried by nitrogen gas. The loading samples were covered by matrix solution ( $0.1 \%$ TFA and $50 \%$ acetonitrile) of $0.8 \mathrm{~L}$. After air-drying, the samples were analyzed by peptide mapping fingerprint (PMF) and MALDI-TOF-TOF-MS, which was rectified by the inner markers including the base peak and the inscribed trypsin peak. The obtained peptide mass fingerprints were used to search through the SWISS-PROT and NCBInr database by the Mascot search engine, with which MS/MS ion search was also finished. In addition, the amino acid sequences of the peptides were deduced with the peptide sequencing program MasSeq.

\section{Results}

2-D electrophoresis maps of sera in control and patients with PSLE

Using gel image analysis software Image Master 2D Platinum 5.0, we compared 2D maps of sera between patients with SLE and healthy controls. The images were found to be similar either between gels or between groups. There were approximately more than 500 spots that could be visualized manually in the $2 \mathrm{D}$ gel images of both pSLE patients and controls. After comparing with the reference gel, match rates of $63 \% \pm 4 \%$ and $62 \% \pm 4 \%$ were for control and patient gels, respectively. Simultaneously, $79 \pm 17$ spots were detected for control gels and $78 \pm 17$ for patient gels. Figure 1 shows a typical control gel and a typical patient gel, respectively.

\section{Differentially expressed proteins between patients with SLE and controls}

To identify proteins that were differentially expressed in one group with respect to the other, we compared the value of expression of each spot in the patient group as a ratio of the value of expression of that spot in the control group using the 'class report' command of Image 


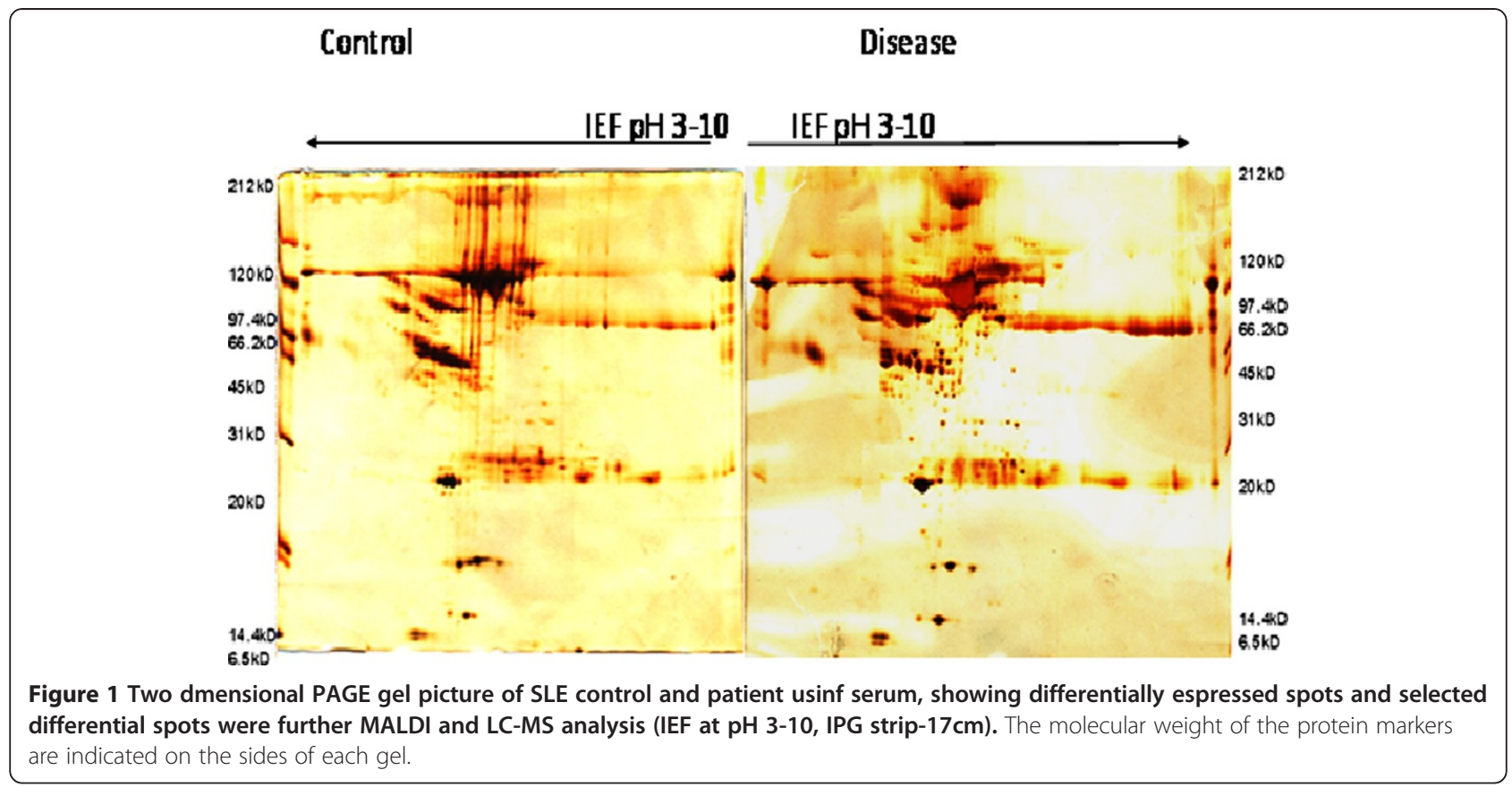

Master 2D Platinum 5.0 for each spot groups. This resulted in 79 spot groups with a between-class ratio of more than one or less than 0.5 . The average value for these spots on the two duplicate gels per individual was calculated, and these average values were then compared using the Mann-Whitney rank sum test, two-tailed. Out of 79 spots, we selected 11 spots for the identification and characterization by MALDI-TOF and LCMS analysis. These protein spots were chosen randomly from the low molecular weight region, preferably at a molecular mass lower than $20 \mathrm{KD}$, as can be seen from their location and labeling in the patent and control gels (Please see Figure 1). LMW proteome, low abundant proteins are especially important for biomarker discovery in SLE. Because this region contains biologic mediators (cytokines, chemokines, growth factors) that are expected to be involved in disease pathogenesis. Some of these mediators have been found in active SLE renal tissue and may reflect organ-specific tissue injury [18]. 2D PAGE followed by MS has been shown earlier to detect urine proteins that discriminate between ISN/RPS lupus nephritis classes [19]. In our cohort, all these 11 spots had $p$ value of less than 0.05 . There were spots which were showing low score in MALDI-TOF. For them we have to proceed further for LC-MS/MS analysis. Six protein spots were up-regulated (labelled as A -11, A-16, A-17, A-18, A-21), and five protein spots were down-regulated (labelled as A-10, A-13 and W) in patients with pSLE (Figure 2). D19 and D31 were the spots highly expressed in the patients. The median volume of the eleven spots in the two groups was also calculated. Figures 3A and $3 \mathrm{~B}$ are enlarged areas of the control and patient gels showing a comparison of the expressions of spot A10 and A21 in these gels respectively.

\section{Identification and characterization of proteins by Mass Spectrometry (MALDI-TOF- MS and LCMS)}

Differentially expressed protein spots were excised from the gels, digested with trypsin and the proteolytic fragments analyzed by MALDI-TOF mass spectrometry as described in materials and methods section. We identified eleven proteins, which are summarized in Table 2 \& 3. Differentially expressed protein spots, their fold regulation values, spot categorization ( $\mathrm{U}$, up-regulated in pSLE; D, down-regulated in pSLE), molecular weight $(\mathrm{MW})$ in daltons $(\mathrm{Da})$, isoelectric point $(\mathrm{pI})$, sequence coverage (\%) of matching peptides and their spectrum analysis are shown in Tables 1 and 2 and Figure 4.

\section{Discussion}

Recently, the proteomic approach has been successively used to identify the biomarkers in skin, kidney or plasma of SLE patients [5,6,20,21]. However, to the best of our knowledge, no such study has been reported on pSLE patients using sera from north India. In this preliminary study, we attempted a proteomic approach such as 2-DE and MALDI-TOF MS and LC-MS to find candidate molecules in sera of pSLE patients with active disease in comparison to age matched healthy controls.

On evaluation of our data five differentially expressed protein spots (within low molecular weight region) were identified: Retinol-binding protein, Leiomodin2, Transthyretin, Component C3c Chain B and Apolipoprotein A1 (Table 2). 


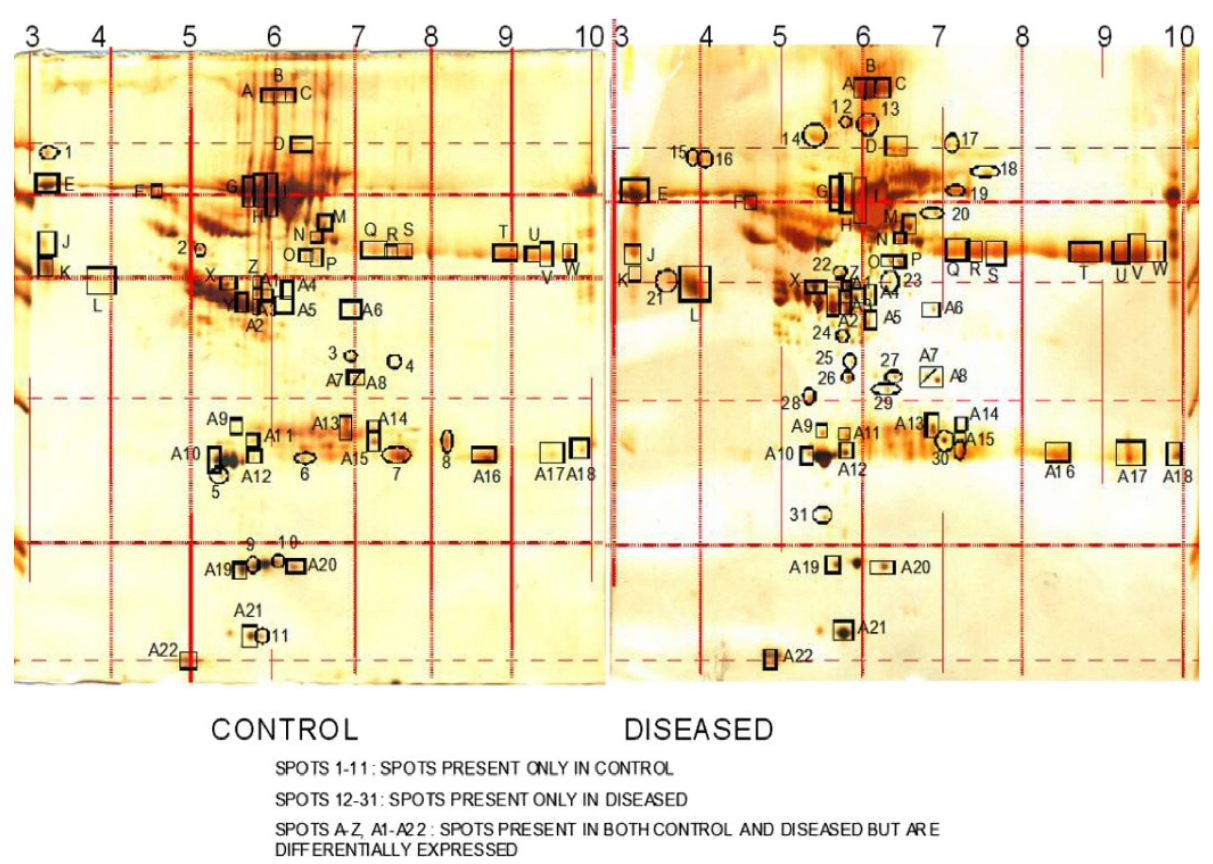

Figure 2 Two dimensional poly acryl amide gel pictures of control and disease using sera shows spots categorization-Spots 1-11: spots present only in control, spots 12-31: Spots present only in diseased, spots A-Z, A1-A22: Spots present in both control and diseased but are differentially expressed.

Retinol binding protein (RBP), a carrier protein that binds to retinol, was found to be over expressed in sera of pSLE patients but not in controls. Its role has been previously described to be associated with nephritis especially in children $[22,23]$. It has also been described as a urinary marker of proximal renal tubular dysfunction [24-26]. We have described the increased expression of RBP protein spots in pooled sera of pSLE patients with active disease and compared them with controls. It would be important to quantitate this protein and discriminate between different sub-groups of patients with pSLE, for example active and non-active disease and with other clinical manifestations (e.g. Lupus nephritis class based on international society of nephrology/renal pathology society classification criteria (WHO/ISN/RPS) which was not covered in this study.

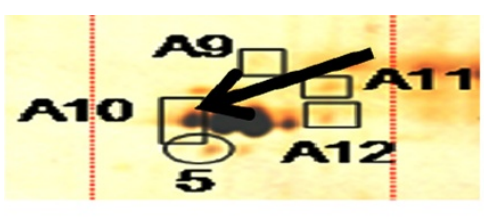

Control

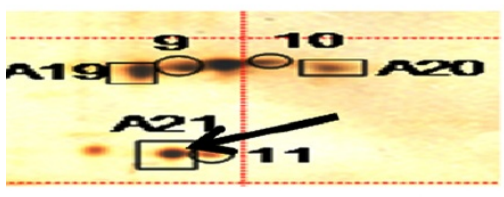

Control

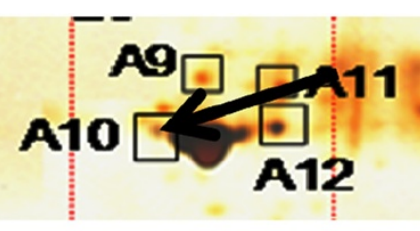

Disease

Figure 3 A Enlarged areas of the control and patient gels showing a comparison of the expressions of spot A10 Apolipoprotein A1 (down regulated in disease as indicated by black arrow) in these gels. On the left is a control gel and on the right is a patient gel. B Enlarged areas of the control and patient gels showing a comparison of the expressions of spot A21 Transthyretin Variant del 122 was over expressed in disease gel (indicated by black arrow) in these gels. On the left is a control gel and on the right is a patient gel. 
Table 2 Spectrum analysis (MALDI-TOF \& LC-MS) results 11 spots

\begin{tabular}{|c|c|c|c|c|c|c|c|c|c|}
\hline S. No & Spot ID & $\begin{array}{l}\text { Accession no } \\
\text { (Database = } \\
\text { NCBI nr) }\end{array}$ & Protein sequence name & $\begin{array}{c}\text { Molecular } \\
\text { mass } \\
\text { (Dalton) }\end{array}$ & $\begin{array}{l}\text { pl } \\
\text { (Isoelectric } \\
\text { point) }\end{array}$ & $\begin{array}{l}\text { Sequence } \\
\text { coverage } \\
\text { MS }\end{array}$ & $\begin{array}{l}\text { Intensity } \\
\text { coverage }\end{array}$ & Score & $\begin{array}{l}\text { No of } \\
\text { peaks }\end{array}$ \\
\hline 1. & A-10 (LC-MS) & gi|178775 & $\begin{array}{l}\text { Pro-apo-lipoprotein } \\
\text { [Homo sapiens] }\end{array}$ & 28944 & 5.13 & $7 \%$ & & 213 & \\
\hline 2. & A-11 (MALDI-TOF) & gi|51095091 & $\begin{array}{l}\text { Leiomodin 2(Cardiac) } \\
\text { [Homo sapiens] }\end{array}$ & 59366 & 9.9 & $14.5 \%$ & $\begin{array}{l}43.7 \% \\
\text { (25167 cnts) }\end{array}$ & 69.4 & 16 \\
\hline 3. & A-13 (MALDI-TOF) & gil78101270 & $\begin{array}{l}\text { Chain B, Human } \\
\text { Complement } \\
\text { Component C3C } \\
\text { [Homo sapiens] }\end{array}$ & 21596 & 5.8 & $18.1 \%$ & $\begin{array}{l}36.3 \% \\
\text { (13319 cnts) }\end{array}$ & 68.0 & 17 \\
\hline 4. & A-16 (LC-MS) & gi|269849769 & $\begin{array}{l}\text { Epidermal cytokeratin } \\
2 \text { [Homo sapiens] }\end{array}$ & 59020 & 5.13 & $7 \%$ & - & 171 & - \\
\hline 5. & A-17 (LC-MS) & gi|29836906 & $\begin{array}{l}\text { Immunoglobulin kappa } \\
\text { light chain variable } \\
\text { region [Homo sapiens] }\end{array}$ & 8811 & 8.65 & $20 \%$ & - & 62 & - \\
\hline 6. & A-18 (LC-MS) & gi|7331218 & Keratin $1[$ Homo sapiens] & 66149 & 8.16 & $3 \%$ & - & 63 & - \\
\hline 7. & A-21 (MALDI-TOF) & gi|212374952 & $\begin{array}{l}\text { Chain A, Crystal structure } \\
\text { of Transthyretin Variant } \\
\text { del 122[Homo sapiens] }\end{array}$ & 13798 & 5.35 & $48.8 \%$ & $\begin{array}{l}33.4 \% \\
(18627 \mathrm{cnts})\end{array}$ & 85.4 & 15 \\
\hline 8. & W (LC-MS) & gi|5542161 & $\begin{array}{l}\text { Chain H, 1.9a Structure } \\
\text { Of The Therapeutic } \\
\text { Antibody Campath-1 h } \\
\text { Fab In Complex With A } \\
\text { Synthetic Peptide } \\
\text { Antigen[Homo sapiens] }\end{array}$ & 23740 & 9.03 & $6 \%$ & - & 105 & \\
\hline 9. & C7 (MALDI-TOF) & gi|222418558 & $\begin{array}{l}\text { Bi-functional Methylene } \\
\text { tetra hydrofolate } \\
\text { de-hydrogenase/ } \\
\text { cyclohydrolase } \\
\text { 2[Homo sapiens] }\end{array}$ & 37463 & 10.0 & $21.3 \%$ & $\begin{array}{l}37.3 \% \\
(18238 \mathrm{cnts})\end{array}$ & 67.00 & 14 \\
\hline 10 & D19 (MALDI-TOF) & gi|119589476 & $\begin{array}{l}\text { Complement component } \\
\text { C3, partial [Homo sapiens] }\end{array}$ & 144417 & 7.8 & $7.5 \%$ & $\begin{array}{l}51.0 \% \\
\text { (34497 cnts) }\end{array}$ & 67.2 & 21 \\
\hline 11. & D31 (LC-MS) & gi|18088326 & $\begin{array}{l}\text { Retinol binding protein } \\
\text { [Homo sapiens] }\end{array}$ & 23371 & 5.77 & $10 \%$ & - & 112 & - \\
\hline
\end{tabular}

Leiomodin 2, also known as cardiac (C) - Lmod2 or Lmod 2, was overexpressed in sera of pSLE patients. It is a 547 amino acid protein that is specifically expressed in heart and skeletal muscles. Leiomodin 2 is encoded by a gene that is located near the hypertrophic cardiomyopathy locus CMH6 on chromosome 7, suggesting that Lmod2 may be involved in that disease process. Tsukada et al. have identified a function of Lmod2 in the

Table 3 Summary of differentially expressed protein spots showing Fold-regulation (Ratio: Diseased/Control as calculated by PD Quest Software)

\begin{tabular}{llllll}
\hline S. No & Spot-No. & Control-Intensity & Diseased-Intensity & Fold regulation & P value \\
\hline 1 & A-10 & 1516.72 & 873.84 & 0.58 & 0.011 \\
2 & A-11 & 411.61 & 597.71 & 1.45 & 0.021 \\
3 & A-13 & 2129.56 & 1635.24 & 0.77 & 0.012 \\
4 & A-16 & 2812.67 & 3452.11 & 1.23 & 0.001 \\
5 & A-17 & 1720.75 & 2687.49 & 1.56 & 0.002 \\
6 & A-18 & 1074.08 & 1666.51 & 1.55 & 0.004 \\
7 & A-21 & 1528.01 & 2347.67 & 1.54 & 0.006 \\
8 & W & 1731.3 & 1082.16 & 0.63 & - \\
9 & Control-7 & 3734.48 & 0 & 0.00 & - \\
10 & Disease-19 & 0 & 2448.43 & 0.00 & 0.00 \\
\hline
\end{tabular}




\section{Spectrum Analysis Report}

\section{Sequence data:}

leiomodin 2 (cardiac) [Homo sapiens]

\begin{tabular}{|c|c|c|c|c|c|}
\hline \multicolumn{2}{|c|}{$\begin{array}{l}\text { Intensity Coverage: } \\
\text { Sequence Coverage MS/MS: }\end{array}$} & $\begin{array}{l}43.7 \%(25167 \mathrm{cnts}) \\
0.0 \%\end{array}$ & $\begin{array}{l}\text { Sequence Coverage MS: } \\
\text { pl (isoelectric point): }\end{array}$ & $\begin{array}{l}14.5 \% \\
9.9\end{array}$ & \\
\hline \begin{tabular}{|l}
10 \\
MSTFGYRRGL
\end{tabular} & $\frac{20}{\text { SKYESIDEDE }}$ & $\frac{30}{\text { LLASLSAEEL }}$ & $\begin{array}{r}40 \\
\text { KELERELEDI }\end{array}$ & $\begin{array}{r}50 \\
\text { EPDRNLPVGL }\end{array}$ & $\begin{array}{r}60 \\
\text { ROKSLTEKTP }\end{array}$ \\
\hline 70 & 80 & 20 & 100 & 110 & 120 \\
\hline TGTFSREALM & AYUEKESOKL & LEKERLGECG & KLSVVARHDE & QELADGGCKS & NSHNRENLRA \\
\hline 130 & 140 & 150 & 160 & 170 & 180 \\
\hline AVGWLGEQGS & CIFKSQIENI & NLTNGSNGRN & TESPAAIHPC & GNPTVIEDAL & DKIKSNDPDT \\
\hline 190 & 200 & 210 & 2.20 & 230 & 240 \\
\hline TEVNLNN IEN & ITTQTLTRFA & EALKDNTVVK & TFSLANTHAD & DSRAMAIAEM & LKVNEHITNV \\
\hline 250 & 260 & 270 & 280 & 290 & 300 \\
\hline NVESNF ITGK & GILAIMRALQ & HNTVLTELRF & HNQRHIMGSO & VEME IVKLLK & ENTTLLRLGY \\
\hline 310 & 320 & 330 & 340 & 350 & 360 \\
\hline HFELPGPRMS & MTSILTRNMD & KOROKRLQEO & KQQEGYDGGP & NLRTKVWQRG & TPSSSPYVSP \\
\hline 370 & 380 & 390 & 400 & 410 & 420 \\
\hline RHSPUSSPKL & PKKVQTKKL I & TRNIAEVIKO & OESAORALON & GQKKKKGKKV & KKQPNS ILKE \\
\hline 430 & 440 & 450 & 460 & 470 & 480 \\
\hline IKNSLRSVOE & KKMEDSSRPS & TPORSAHENL & MEAIRGSSIK & OLKRMTEVPC & DDOMLGOCRV \\
\hline .990 & 500 & 510 & 520 & 530 & \\
\hline TAANEPKYNH & MHOSORLAPO & NKPAFLVRDG & HRML AAS INT & QMI & \\
\hline
\end{tabular}

\section{Display Parameter:}

Sequence Name:

Parentmass:

$\mathrm{MH}+$ (mono):

Threshold (a.i.):

Number of Peaks:

Assigned Peaks:

$\begin{array}{lll}\text { leiomodin } 2 \text { (cardiac) [Homo sapiens] } & \\ 1000.000 & \text { Mass Error: } & 998.992 \\ 1.008 & \text { MH+ (avg): } & 1.008 \\ 0.000 & \text { Tolerance (Da): } & 1.000 \\ 16 & \text { Above Threshold: } & 16 \\ 0 & \text { Not assigned Peaks: } & 16\end{array}$

\begin{tabular}{|r|r|r|r|r|r|}
\hline Peaklist: & \multicolumn{1}{|c|}{} & \\
\hline Peak & Mass & Intensity & Peak & Mass & Intensity \\
\hline 1 & 854.916 & 4464.134 & 2 & 860.944 & 6344.241 \\
\hline 3 & 870.900 & 1269.587 & 4 & 876.924 & 7821.965 \\
\hline 5 & 892.887 & 3136.749 & 6 & 1014.496 & 1180.397 \\
\hline 7 & 1065.955 & 2714.858 & 8 & 1081.913 & 2223.353 \\
\hline 9 & 1156.516 & 1953.268 & 10 & 1200.573 & 4135.187 \\
\hline 11 & 1406.537 & 3857.165 & 12 & 1613.911 & 1886.728 \\
\hline 13 & 1687.953 & 1484.853 & 14 & 1759.002 & 8344.641 \\
\hline 15 & 1811.752 & 1760.113 & 16 & 1887.089 & 4989.753 \\
\hline
\end{tabular}

Matched Sequences:

\section{leiomodin 2 (cardiac) [Homo sapiens]}

MSTFGYRRGLSKYESIDEDELLASLSAEELKELERELEDIEPDRNLPVGLRQKSLTEKTPTGTFSREALMAYWEKESQKLLEKERLGECGKLSVVARHDEQELADGGCKS NSHNRENLRAAVGWLGEQGSCIEKSQIENINLTNGSNGRNTESPAAIHPCGNPTVIEDALDKIKSNDPDTTEVNLNNIENITTQTLTREAEALKDNTVVKTF SLANTHAD DSAAMAIAEMLKVNEHITNVNVESNE ITGKGILAIMRALQHNTVLTELRFHNQRHIMGSQVEMEIVKLLKENTTLLRLGYHEELPGPRMSMTSILTRNMDKQRQKRLQEQ KOQEGYDGGPNLRTKVWQRGTPSSSPYVSPRHSPWSSPKLPKKVQTKKLITRNIAEVIKQQESAQRALQNGQKKKKGKKVKKQPNSILKEIKNSLRSVQEKKMEDSSRPS TPQRSAHENLMEAIRGSSIKQLKRMTEVPCDDQMLGQCRVTAANEPKYNHMHQSQRLAPQNKPAFLVRDGHRMLAASINTQMI

Figure 4 MALDI MS analysis report for a representative protein spot.

regulation of thin filament lengths. Over expression of Lmod 2 results in loss of Tmod1 assembly and elongation of the thin filaments from their pointed ends. Primary function of Lmod2 is to maintain thin filament lengths in the mature heart. It has been shown to be essential for efficient contractile activity of heart and striated muscles. Presence of increased protein in diseased sera may correlate with myocarditis and polymyositis in pSLE patients. This assumption also requires further investigation [27-29].

Transthyretin (TTR) is a serum and cerebrospinal fluid carrier of the thyroid hormone thyroxine (T4) and retinol [30]. TTR variant Del 122 Val protein had a higher expression in pSLE sera compared to healthy controls. Plasma TTR originates primarily from the liver [31]. TTR is known to be associated with the amyloid diseases, senile systemic amyloidosis, familial amyloid polyneuropathy, and familial amyloid cardiomyopathy [32-34]. The presence of this protein in our study suggests that pSLE patients have potential to develop secondary amyloidosis. Sequential quantitation of this protein in long surviving SLE patients and its relationship with development of amyloidosis should be addressed in future studies.

Apolipoprotein A1 (APO A1) is a major constituent of the high density lipoprotein (HDL) complex which acts in cholesterol homeostasis and also has anti-inflammatory 
properties both in acute and chronic inflammation [35]. Serum apolipoprotein (apo) A-I is also considered to be an immune regulator and can suppress pro-inflammatory cytokines generated by activated $\mathrm{T}$ cell in some autoimmune diseases [36]. The present study showed lower expression of apolipoprotein A1 in lupus patients as compared to healthy controls. Zhang, B., et al. (2010) showed lower level of Apo-A-I are seen in SLE and rheumatoid arthritis patients [37]. Further, it has been shown that low levels of this protein are associated with increased risk for cerebrovascular disease and atherosclerosis [38]. This interesting finding in our cohort re-iterates that in future therapeutic modulation of this protein may prevent long term complications of SLE due to exaggerated atherosclerosis.

\section{Conclusions}

In this preliminary proteomic study performed on pooled sera of pSLE patients with active disease, we identified some significant differentially expressed proteins relevant to a pSLE cohort. All novel proteins need validation by ELISA, western blot or by high throughput protein microarray technology. Furthermore, the role of these proteins as prognostic markers in adult and pediatric SLE patients needs further investigation.

\section{Abbreviations}

pSLE: Paediatric Systemic Lupus Erythematosus; 2DPAGE: 2 Dimensional Poly Acryl amide Gel Electrophoresis; MALDI-TOF: Matrix Assisted Laser Desorption Ionization Time of Flight; LCMS: Liquid Chromatography Mass Spectrometry; RBP: Retinol Binding Protein; LMOD2: Leiomodin 2; TTR: Transthyretin; Apolipoprotein A1: APOA1.

\section{Competing interests}

The authors declare that they have no competing interests.

\section{Authors' contributions}

AR executed the study, compiled and analyzed the data, and wrote the manuscript. RWM designed the study, supervised the study, helped with data analysis and edited the manuscript. RA edited the paper, supervised the work and compilation of data. SS supervised part of proteomic work in her lab. SA helped in execution of work. NP helped in execution of the work and compilation of data. SuS participated in the design of the study and helped to draft the manuscript and provided all samples and clinical demographic and laboratory data of pediatric lupus patients. All authors read and approved the final manuscript.

\section{Acknowledgements}

The authors would like to thank The Centre of Genomics and Applications (New Delhi) for MALDI-MS and LC-MS for providing technical assistance.

\footnotetext{
Author details

'Department of Immunopathology, Post Graduate Institute of Medical Education and Research (PGIMER), Chandigarh 160012, India. '2Department of Biochemistry, Post Graduate Institute of Medical Education and Research (PGIMER), Chandigarh 160012, India. ${ }^{3}$ Paediatric Allergy Immunology Unit Advanced Paediatrics Centre, Post Graduate Institute of Medical Education and Research (PGIMER), Chandigarh 160012, India.
}

Received: 19 December 2011 Accepted: 26 June 2012

Published: 17 August 2012

\section{References}

1. Cao MY, Dupriez VJ, Rider MH, Deggouj N, Gersdorff MC, Rousseau GG, Tomasi JP: Myelin protein Po as a potential autoantigen in autoimmune inner ear disease. FASEB J 1996, 10(14):1635-1640.

2. Lee KH, Chung HS, Kim HS, Oh SH, Ha MK, Baik JH, Lee S, Bang D: Human alpha-enolase from endothelial cells as a target antigen of anti-endothelial cell antibody in Behcet's disease. Arthritis Rheum 2003, 48(7):2025-2035

3. Xiang $Y$, Kato $T$ : Use of proteomics in analysis of autoimmune diseases. Lupus 2006, 15(7):431-435.

4. Lambrecht $\mathrm{S}$, Tilleman $\mathrm{K}$, Elewaut D, Deforce D: Proteomics in rheumatology: The beginning of a fairy tale? Proteomics Clin Appl 2008, 2(3):411-419.

5. Dai $Y$, Hu C, Huang Y, Huang H, Liu J, LV T: A proteomic study of peripheral blood mononuclear cells in systemic lupus erythematosus. Lupus 2008, 17(9):799-804.

6. Jin EH, Shim SC, Kim HG, Chae SC, Chung HT: Polymorphisms of COTL1 gene identified by proteomic approach and their association with autoimmune disorders. Exp Mol Med 2009, 41(5):354-361.

7. Kinloch A, Tatzer V, Wait R, Peston D, Lundberg K, Donatien P, Moyes D, Taylor PC, Venables PJ: Identification of citrullinated alpha-enolase as a candidate autoantigen in rheumatoid arthritis. Arthritis Res Ther 2005, 7(6):R1421-R1429.

8. Gorg A, Weiss W, Dunn MJ: Current two-dimensional electrophoresis technology for proteomics. Proteomics 2004, 4(12):3665-3685.

9. Tambor V, Fucikova A, Lenco J, Kacerovsky M, Rehacek V, Stulik J, Pudil R: Application of proteomics in biomarker discovery: a primer for the clinician. Physiol Res 2010, 59(4):471-497.

10. Futcher B, Latter Gl, Monardo P, McLaughlin CS, Garrels Jl: A sampling of the yeast proteome. Mol Cell Biol 1999, 19(11):7357-7368.

11. Varshavsky A: The N-end rule: functions, mysteries, uses. Proc Natl Acad Sci U S A 1996, 93(22):12142-12149.

12. Jackson RJ, Standart N: Do the poly(A) tail and $3^{\prime}$ untranslated region control mRNA translation? Cell 1990, 62(1):15-24.

13. Sheets MD, Fox CA, Hunt T, Vande Woude G, Wickens M: The 3'-untranslated regions of c-mos and cyclin mRNAs stimulate translation by regulating cytoplasmic polyadenylation. Genes Dev 1994, 8(8):926-938.

14. Kontoyiannis D, Pasparakis M, Pizarro TT, Cominelli F, Kollias G: Impaired on/ off regulation of TNF biosynthesis in mice lacking TNF AU-rich elements: implications for joint and gut-associated immunopathologies. Immunity 1999, 10(3):387-398.

15. Tan EM, Cohen AS, Fries JF, Masi AT, McShane DJ, Rothfield NF, Schaller JG, Talal N, Winchester RJ: The 1982 revised criteria for the classification of systemic lupus erythematosus. Arthritis Rheum 1982, 25(11):1271-1277.

16. Gladman DD, Urowitz MB, Kagal A, Hallett D: Accurately describing changes in disease activity in Systemic Lupus Erythematosus. J Rheumatol 2000, 27(2):377-379.

17. Gharahdaghi F, Weinberg CR, Meagher DA, Imai BS, Mische SM: Mass spectrometric identification of proteins from silver-stained polyacrylamide gel: a method for the removal of silver ions to enhance sensitivity. Electrophoresis 1999, 20(3):601-605.

18. Knepper MA: Proteomics and the kidney. J Am Soc Nephrol 2002, 13(5):1398-1408

19. Oates JC, Varghese S, Bland AM, Taylor TP, Self SE, Stanislaus R, Almeida JS, Arthur JM: Prediction of urinary protein markers in lupus nephritis. Kidney Int 2005, 68(6):2588-2592.

20. Fang S, Zeng F, Guo Q: Comparative proteomics analysis of cytokeratin and involucrin expression in lesions from patients with systemic lupus erythematosus. Acta Biochim Biophys Sin (Shanghai) 2008, 40(12):989-995.

21. Zhang $X$, Jin M, Wu H, Nadasdy T, Nadasdy G, Harris N, Green-Church K, Nagaraja H, Birmingham DJ, Yu CY, et al: Biomarkers of lupus nephritis determined by serial urine proteomics. Kidney Int 2008, 74(6):799-807.

22. Stephens P, Edkins S, Davies H, Greenman C, Cox C, Hunter C, Bignell G, Teague J, Smith R, Stevens C, et al: A screen of the complete protein kinase gene family identifies diverse patterns of somatic mutations in human breast cancer. Nat Genet 2005, 37(6):590-592.

23. Dillon SC, Taylor GM, Shah V: Diagnostic value of urinary retinol-binding protein in childhood nephrotic syndrome. Pediatr Nephrol 1998, 12(8):643-647 
24. Guy JM, Brammah TB, Holt L, Bernstein RM, McMurray JR, Tieszen K, Cooper RG: Urinary excretion of albumin and retinol binding protein in systemic lupus erythematosus. Ann Clin Biochem 1997, 34(Pt 6):668-674.

25. Sesso R, Rettori R, Nishida S, Sato E, Ajzen H, Pereira AB: Assessment of lupus nephritis activity using urinary retinol-binding protein. Nephrol Dial Transplant 1994, 9(4):367-371.

26. Smith GC, Winterborn MH, Taylor CM, Lawson N, Guy M: Assessment of retinol-binding protein excretion in normal children. Pediatr Nephrol 1994, 8(2):148-150.

27. Conley CA, Fritz-Six KL, Almenar-Queralt A, Fowler VM: Leiomodins: larger members of the tropomodulin (Tmod) gene family. Genomics 2001, 73(2):127-139.

28. Chereau D, Boczkowska M, Skwarek-Maruszewska A, Fujiwara I, Hayes DB, Rebowski G, Lappalainen P, Pollard TD, Dominguez R: Leiomodin is an actin filament nucleator in muscle cells. Science 2008, 320(5873):239-243.

29. Tsukada T, Pappas CT, Moroz N, Antin PB, Kostyukova AS, Gregorio CC: Leiomodin-2 is an antagonist of tropomodulin-1 at the pointed end of the thin filaments in cardiac muscle. J Cell Sci 2010, 123(Pt 18):3136-3145.

30. Zheng W, Lu YM, Lu GY, Zhao Q, Cheung O, Blaner WS: Transthyretin, thyroxine, and retinol-binding protein in human cerebrospinal fluid: effect of lead exposure. Toxicol Sci 2001, 61(1):107-114.

31. Connors LH, Lim A, Prokaeva T, Roskens VA, Costello CE: Tabulation of human transthyretin (TTR) variants, 2003. Amyloid 2003, 10(3):160-184.

32. Ingenbleek $Y$, Young $V$ : Transthyretin (prealbumin) in health and disease: nutritional implications. Annu Rev Nutr 1994, 14:495-533.

33. Rudin DO: The choroid plexus and system disease in mental illness. III. The exogenous peptide hypothesis of mental illness. Biol Psychiatry 1981, 16(5):489-512.

34. Jacobson DR, Reveille JD, Buxbaum JN: Frequency and genetic background of the position 122 (Val--lle) variant transthyretin gene in the black population. Am J Hum Genet 1991, 49(1):192-198.

35. Shoenfeld Y, Szyper-Kravitz M, Witte T, Doria A, Tsutsumi A, Tatsuya A, Dayer JM, Roux-Lombard P, Fontao L, Kallenberg CG, et al: Autoantibodies against protective molecules-C1q, C-reactive protein, serum amyloid $P$, mannose-binding lectin, and apolipoprotein A1: prevalence in systemic lupus erythematosus. Ann N Y Acad Sci 2007, 1108:227-239.

36. Burger D, Dayer JM: High-density lipoprotein-associated apolipoprotein A-I: the missing link between infection and chronic inflammation? Autoimmun Rev 2002, 1(1-2):111-117.

37. Zhang B, Pu S, Li B, Ying J, Song XW, Gao C: Comparison of serum apolipoprotein A-I between Chinese multiple sclerosis and other related autoimmune disease. Lipids Health Dis 2010, 9:34.

38. McMahon M, Grossman J, FitzGerald J, Dahlin-Lee E, Wallace DJ, Thong BY, Badsha H, Kalunian K, Charles C, Navab M, et al: Proinflammatory high-density lipoprotein as a biomarker for atherosclerosis in patients with systemic lupus erythematosus and rheumatoid arthritis. Arthritis Rheum 2006, 54(8):2541-2549.

doi:10.1186/1546-0096-10-24

Cite this article as: Rana et al:: A comparative proteomic study of sera in paediatric systemic lupus erythematosus patients and in healthy controls using MALDI-TOF-TOF and LC MS-A pilot study. Pediatric Rheumatology 2012 10:24.

\section{Submit your next manuscript to BioMed Central and take full advantage of:}

- Convenient online submission

- Thorough peer review

- No space constraints or color figure charges

- Immediate publication on acceptance

- Inclusion in PubMed, CAS, Scopus and Google Scholar

- Research which is freely available for redistribution 